\title{
CORRIGENDUM
}

\section{Anticancer oncolytic activity of respiratory syncytial virus}

\section{Echchgadda, S Kota, I DeLa Cruz, A Sabbah, T Chang, R Harnack, V Mgbemena, B Chatterjee and S Bose}

Cancer Gene Therapy (2009) 16, 936; doi:10.1038/cgt.2009.42

Correction to: Cancer Gene Therapy (2009) 16, 923-935; doi: 10.1038/cgt.2009.34; published online 15 May 2009

In this article, an error appears in the author affiliation details. Dr Ibtissam Echchgadda is only affiliated with the Department of Molecular Medicine at University of Texas Health Science Center at San Antonio and not with Department of Microbiology and Immunology. 